This chapter is the author accepted manuscript forthcoming in:

Peter Cane, Herwig Hofmann, Eric Ip and Peter Lindseth eds., The Oxford Handbook of

Comparative Administrative Law (2020)

\begin{tabular}{|l|} 
This chapter compares the respective roles of administrative institutions and \\
administrative power on the one hand, and other governmental institutions and \\
powers on the other, in dealing with drug use, possession, and trafficking in China \\
and Victoria (Australia). Comparison of these two jurisdictions provides both \\
opportunities and challenges. Though one is a nation-state, the other a sub-national \\
offending. There is thus comparability in terms of jurisdiction. More importantly, the \\
opportunities and challenges for comparison stem from the divergence in fundamental \\
political system; one authoritarian and one liberal democratic, and the nature of the \\
relationship between state and citizen that flows from this. This divergence has \\
implications for selection of both comparative methodology and the subject matter of \\
comparison.
\end{tabular}




\title{
ADMINISTRATIVE POWER
}

\author{
SARAH BIDDULPH ${ }^{1}$
}

\subsection{Introduction: Administrative Power and the Task of Comparison}

Instead of analysing the nature of administrative power generally in relation to other governmental powers, this chapter compares the respective roles of administrative institutions and administrative power on the one hand, and other governmental institutions and powers on the other, in dealing with drug use, possession, and trafficking in China and Victoria (Australia), the two jurisdictions with which I am most familiar. Comparison of these two jurisdictions provides both opportunities and challenges. Though one is a nation-state, the other a sub-national state within a federation, both have jurisdiction to regulate drug use-related harms and offending. There is thus comparability in terms of jurisdiction. More importantly, the opportunities and challenges for comparison stem from the divergence in fundamental political system; one authoritarian and one liberal democratic, and the nature of the relationship between state and citizen that flows from this. This divergence has implications for selection of both comparative methodology and the subject matter of comparison.

\footnotetext{
${ }^{1}$ This research was supported by a grant from the Australian Research Council (Grant no.
} FT130100412). 
Before proceeding to the substantive discussion, in this introduction, I first map the process of shaping an approach to both the topic of administrative power and to comparison. That is because finding a location from which profitably to examine two very different jurisdictions, particularly in relation to a subject matter as vast and multifaceted as administrative power, involves choices and judgements that will highlight certain aspects of administrative power more than others. These choices will also locate the jurisdictions in a particular relationship with each other. The reasons and justifications for these choices should be made transparent to the reader, if only to illuminate that what follows is just one out of many fruitful ways of engaging with this fascinating topic.

\subsubsection{Approaches to Administrative Power}

Some approaches are deeply normative. Analyses focusing on the administrative state, or the extent and implications of contracting functions to private providers previously performed by government, concern the proper scope of administrative power and the conditions for private implementation of those functions. The challenge presented by trans-national or global administrative law is to the conventional wisdom that links administrative power with the governments of nationstates. This body of work also suggests we be sensitive to the demise, and then resurgence, of the nation-state.

Another approach is to examine what administrative power is by looking at the ways in which administrative power is legally constituted, bounded, and supervised, as well as the conventions, norms, and practices affecting its distribution and exercise (Cane 2016, 2-3). Administrative power may be constituted positively, by way of a written constitution, by legislation or prerogative; or negatively, by the doctrine of 
ultra vires or judicial review, where the substance and procedural limits of administrative power are ultimately determined. As Cane (2016, 4) explains, the constitution and control of administrative power are two sides of the same coin, with control mechanisms themselves constitutive of the boundaries of administrative power 'and so a part of its definition'. Framed normatively, this approach interrogates the appropriate scope and manner of exercise of administrative power, judged with reference to principles of rule of law and democratic governance.

This chapter seeks to change the primary location of the inquiry to the grassroots and examine the question of 'where is administrative power'. The analysis of 'where administrative power' is exercised to address a specific social problem invites mapping of how and where administrative power is exercised in society, its boundaries, limits, and relations to other forms of judicial, social, and political power. This micro-level analysis not only tests, but also contributes to building a more nuanced understanding of macro-level inquiries into the constitution of administrative power and the questions that this broader level inquiry raises about the relationship between administrative power, law, and politics.

\subsubsection{Approaches to Comparison}

Selecting an approach to the substantive topic is limited by the second task of this chapter, that is, comparison. Traditional functional methodology in comparative law attempts to find problems commonly faced within different jurisdictions, and to compare possible legal solutions to those problems. Such a model imagines the placement of jurisdictions in theoretically equal positions as both are scrutinized and evaluated in relation to the function or problem to be elucidated (Zweigert and Kotz 1998). 
But we know that the act of comparison is not neutral (Frankenberg .1985; Nicholson and Biddulph 2008.). The questions we ask about administrative power and the way in which we construct our inquiry inevitably reflect what substantively we consider to be important, and how we see the jurisdictions in relation to each other. A question that may be topical, contested, and important in one jurisdiction may be well settled, not interesting, or even a non-issue in another. When the constitutional structure and basic political values of the jurisdictions to be compared are similar, this task is easier; conversely, when there are marked differences between the jurisdictions in these fields, comparison becomes problematic. As Kahn-Freund (1974, 11) argues, the closer the topic to the country's core political system (as administrative power is) the more fraught the task of comparison. ${ }^{2}$. It is more likely, for example, to find current questions about administrative power that are front of mind in both England and Victoria, than, for example, in China and Victoria. Where the state structure and political values of the compared systems differ, as in the case of China and Victoria, finding a point of comparison becomes more complex.

When we compare administrative power in a democratic and an authoritarian state, the order of comparison becomes consequential if the analysis is not to be shaped in such a way that our conclusions collapse into simplistic assertions about human rights and its absence, and rule of law and its absence. Additionally, as Teemu Ruskola (2002, 12) contends, in the prevailing Western imagination, China is a lawless place, readily turned into the 'other', measured in terms of its distance from the rule of law ideal of a democratic polity. This insight suggests comparison must be

\footnotetext{
${ }^{2}$ Kahn-Freund was primarily interested in the success of legal transplants, but the basic point remains.
} 
organized in a way that avoids placement of the systems to be compared in the relation of normative centre and periphery.

My approach follows the prescription of Horowitz (2003, 2) who, in discussing the comparatist Herbert Bernstein, notes two important prescriptions about comparison. The first is that 'intelligent comparative work' can only proceed by 'getting down to specifics' and 'getting them right'. The second is to get the big picture right as otherwise 'comparison of the particulars by themselves would be incomprehensible, even incoherent' (Horowitz 2003, 4).

This chapter takes up this dual challenge, to pay attention to the particulars and to get the 'big picture' right. This relationship is mapped both in terms of the exercise of administrative power and jurisdiction. The particulars are located in case studies, examining the location of administrative power in the policy, law, and practice of the treatment of drug dependency in China and Victoria, starting with an examination of the Chinese situation. Its focus is on the question of 'where is administrative power', that directs us to administrative power where it is exercised in the community. Drug misuse is an intractable problem worldwide and involves application of a mixture of educational, welfare, coercive, and punitive elements against people who are readily marginalized by government and community alike. Both China and Australia grapple, mostly unsuccessfully, with problems of drug dependency. Both jurisdictions have drug policies that profess some commitment to harm reduction and have deployed a wide range of resources to addressing this social problem. Administrative powers are part of this mix and so a focus on drug policy helps to locate administrative power 
amongst other types of power; judicial, political, and social, as well as amongst different administrative actors.. ${ }^{3}$

Before delving into the selected cases, I will address the big picture question, so that the case study can become intelligible. I explain the basic frameworks within which my case studies are located, discussing the relationship between administrative power, law, and politics. I then proceed to the case studies. My preliminary conclusions are that the allocation of judicial, administrative, and social power in addressing problems of drug use and dependency differ significantly in the two jurisdictions and that these differences align with broader system level divergences in the configuration of state power and the relationship between state and society.

\footnotetext{
${ }^{3}$ I am using the term social power in two senses. The first is to distinguish it from administrative and other forms of governmental power exercised by state agencies and from political power exercised by the Chinese Communist Party. The second is to identify the possibility of a locus of power exercised by sometimes-organized private actors in the public sphere, outside that of the Party-state, that might seek to influence state and Party actors, or to intervene where possible in supporting drug dependent people. Another reason for using the term social power is to avoid introduction of assumptions about comparability between Victoria and China that might arise from the use of more conceptually fixed and ideologically significant terms such as 'civil society'. This chapter uses the idea of 'social power’ rather than Habermas' concept of the public sphere, or Bourdieu’s concept of social capital, as social power directs our attention to societal (as opposed to governmental) actors in the public sphere whose 'social capital' or capacity to act and influence is variable, even ephemeral in the face of Party-state organization and exclusion, and who are sufficiently peripheral to policy formation and implementation, that a claim that they are ‘civil society’ actors cannot be made without more detailed analysis and justification.
} 
Ultimately, though, the impact of these differences does not prevent drug users in both jurisdictions remaining marginalized.

\subsection{Basic Frameworks: The Big Picture}

The big picture requires attention to key questions about the relationship between administrative power, law, legality, and politics, and provides the context for examination of more specific questions about administrative power.

China's embrace of law as a tool of governance has undergone dramatic transformation since the Chinese Communist Party ('Party') took power in 1949. In the Maoist, or revolutionary era, legal forms of governance were weakly institutionalized and periodically overwhelmed by revolutionary mass campaigns, particularly in the early 1950s, from 1957 to 1961 with the Anti-Rightist Campaign and Great Leap Forward and between 1966 and 1976 with the Cultural Revolution. Conflicts were handled based on class status (as a member of the 'people' or the 'enemy') rather than in accordance with law and fact. Only after 1979 did the Party, under Deng Xiaoping, commit to reconstructing a modern legal system and legal institutions and to restrict the scale and frequency of campaigns. From 1997, the Party made an explicit commitment to law-based governance, framed as 'socialist rule of law'.

Today, at the most abstract level, we can point to some common principles in both jurisdictions; administrative power is created by and must be exercised lawfully and should respect human rights. But beyond the level of assertion of basic principle, the ways these principles are given shape diverge. In the Chinese case, the fundamental relationship between administrative power, legality, and politics has 
become unsettled. In Victoria, by contrast, whilst uncertainties and contentious issues arise in areas of application, at the level of basic principle, the relationship between legality, politics, and administrative power are comparatively stable.

\subsubsection{Law and Politics}

In China, despite strong rhetorical commitment to a 'socialist rule of law', the relationship between administrative power, the rule of law, and politics is not only unclear in practice, but increasingly ambiguous in principle. Until recently, scholars have imagined a form of separation of Party and state under which Party matters were governed by the Party Charter and state business was governed by the state constitution and laws made under it (Backer 2009, 605-7; Jiang 2010). In both theory and practice this distinction is undermined by Party control of the boundary between Party and state (Li 2015, 95-6). But, particularly since 2014, even this form of conditional separation has eroded.

While the Party has always asserted its leadership over the rule of law (it was after all a Party decision to re-establish law as a mode of governance and the Party that invested heavily in establishing and supporting development of its version of rule of law), in 2014 the intensity of Party leadership over law and legal institutions changed. From 2014, the Party’s Central Committee made clear its resolve to recentralize power over legal administration, impose more extensive requirements of political correctness in administration under the rubric of exercising 'absolute' leadership over the rule of law, and to strengthen politicization of legal personnel and agencies (Trevaskes 2018, 348). In January 2019 the Party’s Central Committee issued the Regulations on Political-Legal Work with the objective of 'upholding and strengthening the Party's absolute leadership over political-legal work' (Article 1) and 
required agencies to adhere to the principle of resolving conflicts based on application of ideologically determined categories of 'the people' and 'the enemy' and 'accurate application of the people’s democratic dictatorship’ (Article 6(6)).. ${ }^{4}$ These ideologically derived status categories do violence to the basic rule of law principle of equality before the law. The political-legal organs referred to are the procuratorate, courts, and police, justice and state security agencies; which together exercise the state's coercive judicial and administrative power. As we will see in the case studies, implementation of drug policy is concentrated in the hands of these organs.

Absolute leadership has progressively been implemented in ways that further undermine institutional and ideological boundaries between Party and state agencies. Recent illustrations are found in decisions of the National People's Congress (NPC) in its 2018 meeting. One amended the state constitution to create a new state anticorruption body directly subordinate to the NPC. The National Supervision Commission is responsible for implementing Xi Jinping’s anti-corruption campaign and for enforcing political discipline on Party members (Li 2019). Controversially, it was created by incorporating a state agency, the Ministry of Supervision (an administrative agency originally under the State Council), the anti-corruption divisions of the nominally independent People's Procuratorate and the Communist Party’s Central Commission for Discipline Inspection. It thus brought together state and Party organizations within the state structure. It exercises powers that blur the boundaries between investigation and punishment of Party disciplinary breaches and legal breaches. Another decision was to transfer some state agencies to Party organs.

\footnotetext{
${ }^{4}$ Accessed at <http://www.gov.cn/zhengce/2019-01/18/content_5359135.htm>.
} 
The State Administration of Religious Affairs, for example, was transferred to the Party’s United Front Work Department (Cabestan 2019.).

The significance of these changes for the present case study is that Party directives about enforcement priorities, particularly during campaigns where politicallegal agencies are required to coordinate their activities to punish targeted activities swiftly and harshly, have a direct and deleterious effect on protection of human rights, procedural fairness, and principles of proportionality.

These changes cannot be seen as a simple reversion to the pre-1978 revolutionary era style of personalized governance as, since 1997, the Party has strengthened professionalism of administrative agencies and other legal and judicial actors, built a more gap-free legislative framework to regulate substantive and procedural aspects of administrative power, and increased the scope of legal accountability mechanisms. However, constructing rule of law has not been designed to separate legal and political power, but to better harness legal power, including law-based administration, to buttress political power. In Victoria, it might be argued that the relationship between political and legal power is the reverse; acting constitutionally and legally bolsters the legitimacy of both state institutions and political actors; that is the ideological function of the rule of law.

In jurisdictions such as Victoria, constitutional allocation of power, the boundary between administrative and political power, and the principles that locate that boundary, are stable. Controversial issues abound, such as the scope of delegated legislation, efforts to avoid liability or existing controls on administrative power by contracting out or creating public authorities, or disputes such as the grounds for ministerial intervention in planning processes. However, these issues can be managed within the framework of constitutional law and conventions. Well-established 
conventions also exist to determine when a court will intervene in the exercise of discretion. The point is that these controversies do not call into question basic constitutional arrangements but arise and are resolved within the bounds of established law and convention.

\subsection{Where is Administrative Power? A View from}

\section{the Ground}

\subsubsection{Dealing with Drug Users and Drug-Dependent People in}

\section{China}

\subsubsection{A politically charged history}

China’s drug policy has a long and politically charged history. Anti-drug propaganda continues to link drug abuse with China’s defeat in the two opium wars (1839-42 and 1856-60) and the ‘century of humiliation’ that followed (State Council Information Office 2000a; Baumler 2007; Zhang and Chin 2018, 6-7). An early campaign after the Party seized power in 1949 was to eradicate narcotic manufacture, trafficking, and dependency. In that campaign, the Party-state's coercive power was amplified by mass mobilization; eliding political, administrative, judicial, and popular power. Its symbolic importance was to demonstrate the capacity of the Party to effect radical and transformative changes in society (Dutton 1995, 437). Even today, where the Party has committed to governing by law, drug policy and enforcement practice remain politically inflected (Zhou and Wang 2016, 201). 


\subsubsection{Drug policy}

Today, drug control policy is administered by the National Narcotics Control Commission (NNCC) established in 1990 under the State Council, with its secretariat and operations directed by the Ministry of Public Security’s Drug Control Bureau (State Council Information Office 2000a).

From 2005, drug policy has been conducted under the rubric of the People’s War on Drugs, requiring that priority being given to ongoing anti-drug campaigns. Very severe criminal punishment is prescribed. The Criminal Law (Article 347) imposes between fifteen years’ imprisonment and death for smuggling, trafficking, transporting, or manufacturing illicit drugs. ${ }^{5}$. The death penalty may be imposed for over 50 grams of heroin or methamphetamine regardless of purity. During periods of campaign, agencies are set enforcement targets to encourage full enforcement and severity is demonstrated through exercising discretion to punish as harshly as possible.

Alongside the People's War sits the 'new' regulatory approach to drug users that characterizes them as 'sick' and 'victims' of dependency rather than offenders (State Council Information Office 2000b). To the extent that there was tension between the People's War and a more humane, harm-reduction approach to drug dependency in terms of allocation of resources and enforcement priorities, the 2014 Opinion on Strengthening the Work of Drug Prohibition issued by the Party Central Committee

\footnotetext{
${ }^{5}$ National People's Congress, Criminal Law of the People's Republic of China (Zhonghua Renmin Gongheguo xing fa) adopted on 1 July 1979 (amended 1997, 1999, 2001, 2002, 2005, 2006, 2009, 2001, 2015, and 4 November 2017, effective on 4 November 2017).
} 
and the State Council resolved it in favour of a national security approach. ${ }^{6}$. From July 2014, drug rehabilitation has been framed in terms of protecting the long-term stability of the nation. While this document identifies improving employment and social welfare assistance and strengthening HIV prevention work amongst drug users, most of the contemplated measures are designed to strengthen 'comprehensive management measures' and control of drug users. ${ }^{7}$

\subsubsection{Measures for dealing with drug users}

In China, in contrast to Victoria, illicit drug use is not characterized as a crime but as an unlawful act, punished administratively. Alongside voluntary rehabilitation, Chinese law prescribes an interlocking set of administrative powers for the management, treatment, and punishment of illicit drug use. Whilst encouraging harm reduction and voluntary rehabilitation, the model described below is ultimately strongly state-centred and coercive in that power is concentrated in the hands of the police and justice departments and focuses on management and control of drug users.

\subsubsection{Harm reduction measures and community participation}

A person may voluntarily seek treatment for drug dependency without punishment in a not-for-profit drug treatment centre accredited and supervised by the health authorities. Methadone substitution programmes (MMT) operated by the health

\footnotetext{
${ }^{6}$ Chinese Communist Party Central Committee, State Council Opinion on Strengthening the Work of Drug Prohibition (Zhonggong Zhongyang, Guowuyuan guanyu jiaqiang jindu gongzuo de yijian) 6 July 2014.

${ }^{7}<$ http://www.gov.cn/xinwen/2014-07/06/content_2713194.htm.
} 
authorities began from 2002 and have gradually become more readily available (Zhang and Chin 2018, 5).

But, to access any of these forms of treatment, a drug user must be entered on a police register (Drug Prohibition Law, Article 36), with negative consequences.. ${ }^{8}$. People on the register have their identity card 'flagged' so that every time they use their identity card; for example, to check into a hotel, or to purchase travel tickets, the local police are notified. Police may conduct random drug tests, often in circumstances that humiliate the person in front of colleagues, friends, and family. People who relapse may be subject to compulsory orders imposed by the police. In practice, it is widely acknowledged that the register is very far from comprehensive, with heroin users more readily discovered than users of other types of illicit substances (Zhang and Chin 2018). It is also not surprising that many shun voluntary treatment to avoid being entered on the register.

Actors such as social workers and volunteers are not, as we might assume, independent of government but are either agents of, or organized by, government agencies. Social workers are employed by local governments to implement community-based coercive orders. Their focus is on monitoring, with limited resources for counselling or providing assistance in finding employment or housing (Biddulph and Xie 2011).

Similarly, the use of the term 'volunteers' is misleading as volunteering is often organized by the work unit or educational institution. Volunteering is invested with significance by (and as part of realizing) Xi Jinping's political agenda of

\footnotetext{
${ }^{8}$ NPC Standing Committee, Drug Prohibition Law of the People's Republic of China, (Zhonghua Renmin Gongheguo jindu fa) passed 29 December 2007, effective 1 June 2008.
} 
'rejuvenation of the Chinese nation' as a method by which the state develops citizens' sense of responsibility (Zhang and Li 2015, 36). The idea of 'volunteering' itself and establishment of volunteering organizations have been actively encouraged by the civil affairs administration, local governments, and the Communist Youth League using material incentives such as volunteering quotas and performance targets, or preference in hiring decisions (Spires 2018, 204, 207-8).

The number of independently organized local community outreach groups conducting harm minimization functions such as education and providing needle exchange remains small. These organizations are often hampered by their unstable working relationship with the police, particularly if they are staffed by former drug users, in that police may patrol or detain people using the service (Zhang and Chin 2018, 6). This policing practice contrasts with that of Victoria Police of generally not patrolling or arresting people using facilities such as the trial Medically Supervised Injecting Centre in North Richmond, discussed below.

\subsubsection{Compulsory drug rehabilitation}

Police powers range from imposition of a small fine or administrative detention of between ten and fifteen days, up to administrative detention for two years. A characteristic of these administrative powers is that the law fails to specify criteria to shape discretion, giving police relatively unfettered powers to determine which of several possible sanctions to impose and the duration of the particular sanction. The lawfulness of administrative decisions may be challenged in court under the Administrative Litigation Law, but a successful challenge is difficult. That is both because the criteria of lawfulness are vague and because individuals face practical 
disincentives to challenging police decision-making when they are under their control or in custody. ${ }^{9}$

The Drug Prohibition Law prescribes a series of interlocking compulsory orders for drug-dependent people imposed by the police. The first is supervised rehabilitation in the community. This is a three-year compulsory order imposed by the police on people determined to be drug-dependent (Drug Prohibition Law, Article 33). Under this order the person is required to sign an agreement with the local street committee (a delegated body of the local government) setting out the period of rehabilitation, treatment measures, and obligations. Agreements impose zero tolerance conditions for performance of the agreement and prevent the person from leaving the district without permission. Zero tolerance means that if the person is caught using illicit drugs during the period of the agreement, they may be sent to an administrative detention facility.

Another community based compulsory order is called 'Recovering Health in the Community’ (shequ kangfu) imposed by the police for between one and three years after release from detention. This order may be served in the community under conditions similar to Community Rehabilitation (Drug Prohibition Law, Article 48, Drug Rehabilitation Regulations, Articles 15, 34), or in a closed facility (Drug Prohibition Law, Article 43). Entry into a closed facility is theoretically voluntary, but in practice many have no choice because of unemployment, homelessness, or family pressure.

\footnotetext{
${ }^{9}$ National People's Congress, Administrative Litigation Law of the People's Republic of China (Zhonghua Renmin Gongheguo xingzheng susong fa) adopted on 4 April 1989, effective 1 October 1990 (amended by the NPC Standing Committee on 1 November 2014, and 27 June 2017, effective 1 July 2017).
} 
Police may impose an initial two-year period of administrative detention under Compulsory Quarantine for Drug Rehabilitation (CQDR) (Drug Prohibition Law, Article 38), in a detention centre operated by the Justice Department. Detainees first undergo detoxification and then participate in work. In some better resourced camps, education and (rarely) psychosocial counselling programmes are provided (Zhang and Chin 2018, 4-5). Where the person is determined to have rehabilitated well, their term may be reduced by one year, or where they have not, extended by one year (Drug Prohibition Law, Article 47). The law itself does not provide any criteria for determining whether the detainee has 'rehabilitated well'.

Some sense of the scale of compulsory drug rehabilitation orders in China is provided in the NNCC's annual report for 2016; 357,000 person-units were sent to CQDR, 245,000 person-units were subjected to Giving up Drugs in the Community Orders and 59,000 to Recovering Health in the Community Orders, and 2,505,000 people were registered as drug users. ${ }^{10}$

\subsubsection{Resources}

What the account above obscures is the systematic lack of capacity of these agencies to implement community-based compulsory orders and the overall weakness of community-based support programmes. There is widespread official acknowledgement that local street committees do not have the financial resources, suitable premises, or specialist personnel required (Xie 2015, 87). It is not surprising, then, that the two community-based orders have been poorly implemented (and in

${ }_{10}$ China Police Web, 23 March 2017, at <http://www.nncc626.com/201703/23/c_129516372.htm $\geq$. 
some cases not implemented at all) and that there are high relapse rates, high unemployment, and high rates of drug-related crime amongst former offenders (Xie 2015, 87). For example, in Chongqing from 2012, street committees delegated management of community-based rehabilitation orders to a joint management committee including officials from the administrative detention centre. Management of these drug users was strengthened through use of a computerized dynamic management system, able to track compliance with elements of the order such as attendance at meetings, whether the person has left the designated local area without permission, or failed to present for regular drug testing (Xie 2015, 89). Lack of resources and training at the community level has thus led to a creeping expansion of punitive powers and approaches in practice.

\subsubsection{Drug Policy in Victoria}

\subsubsection{History and overview}

In Australia, the national drug policy framework was adopted in 1985 (National Drug Strategy, NDS). In contrast to the Chinese situation, problems with recreational use of illicit drugs are comparatively recent in Australia and burdened with less political symbolism touching on sovereignty and national dignity. The NDS comprises three pillars: demand reduction, supply reduction, and harm reduction (VLRRCSC 2018, 53). It articulates a harm minimization approach focusing on reducing the harms of drug use, rather than reducing drug use and so does not draw a strong distinction between licit and illicit drugs, in contrast to the Chinese drug policy focus on illicit drugs. 
An Inquiry into Drug Law Reform conducted by the Parliament of Victoria, Law Reform, Road and Community Safety Committee (VLRRCSC) in 2018 helpfully provides a comprehensive evaluation of the laws, programmes, and policies for addressing illicit drug use in Victoria.. ${ }^{11}$. This report notes that despite the official policy approach to drugs being harm reduction, much effort is still placed on 'law enforcement to reduce the supply of illicit drugs'. It argues that better outcomes would be achieved with a greater balance between law enforcement and health-based responses (VLRRCSC 2018, 2, 61). To achieve this it recommends a four-pillar approach of prevention, law enforcement, treatment, and harm reduction, to facilitate higher funding of treatment and harm reduction programmes through identification of treatment and harm reduction as distinct and separate (VLRRCSC 2018, 79). By design, drug policy in Victoria is not only an all of government approach (including state and federal agencies) but also incorporates community and other expert voices into policy formation and implementation.

The difference between approaches in drug policy, arguably reflects broader differences in styles of governance between Victoria and China. China's is strongly state-centred, with civil society playing a marginal, supportive role. In Victoria, independent non-government and civil society actors play a central role, in terms of both policy formation and provision of services.

\subsubsection{Measures for dealing with drug users}


In contrast with the Chinese situation which distinguishes between administrative and criminal wrongs, in Victoria all illicit drug offences are criminal and may be punished either as a summary or indictable offence. Use of a drug of dependence is a summary offence under the Drugs, Poisons and Controlled Substances Act 1981. ${ }^{12}$. This offence may be punished with a fine or imprisonment of up to one year. Possession of a drug of dependence is an indictable offence under section 73 of the Drugs, Poisons and Controlled Substances Act 1981. If it is determined that possession was not for the purposes of trafficking, this offence may be punished by a fine or imprisonment of up to one year. Punishment for trafficking (which is distinguished from possession by quantity) varies from fifteen years' to life imprisonment depending on quantity and type of substance. Unlike China, the purity of the drug is taken into account in determining the quantity trafficked and the level of penalty.

Most prosecutions for drug-related offences in Victoria are for using and or possessing illicit drugs, as opposed to supply-related offences such as importation, trafficking, selling, cultivation, and manufacture, but police report that use and possession are usually detected in practice when a person is arrested for committing some other crime that flows from, or is associated with, drug use (VLRRCSC 2018, 157).

\subsubsection{Institutional division of power}

Criminalization of drug use and possession in Victoria dramatically changes the balance between judicial and administrative power in implementing drug policy. In

\footnotetext{
${ }^{12}$ Drugs, Poisons and Controlled Substances Act 1981, Act No. 9719 of 1981, Victoria, incorporating amendments as at 1 July 2018.
} 
China, as noted above, the courts are almost entirely absent in addressing drug use and dependency and are confined primarily to adjudicating criminal supply-type offences. The judicial role in Victoria extends well beyond adjudication of criminal cases with courts.

The Magistrates' Court of Victoria administers a range of diversion programmes to provide case management and access to services where substance-use disorders contributed to offending. Offenders may be referred to community support services, such as housing support, anger management and psychological counselling, disability services, mental health services, and drug and alcohol treatment. These programmes include the Court Integrated Services Program (CISP) and CREDIT/Bail support programmes (VLRRCSC 2018, 196-9). In Victoria, Drug Court has operated since 2002 as a division of Magistrates' Court of Victoria. It may impose a drug treatment order (DTO) (under section 18z of the Sentencing Act 1991) which is a judicially supervised, therapeutic order. Under a DTO the Justice Department case-manages, and the magistrate supervises compliance with, the conditions imposed by the court to assist the person to address problems associated with drug dependence. Many not-forprofit organizations and private treatment providers are funded or supported to provide mandated services (VLRRCSC 2018, 205)...

Not only is judicial power central in dealing with drug dependency, courts also coordinate and bring services and treatment providers into the heart of the criminal process through treatment and support programmes. Institutionally, civil society and other private actors become located more centrally in formal justice processes through therapeutic approaches to justice than the Chinese approach allows.

\footnotetext{
${ }^{13}$ Sentencing Act 1991 No. 49 of 1991 Victoria, incorporating amendments as at 1 July 2010.
} 
Police diversion programmes also play a significant role after a person is apprehended for drug use and possession, but before a charge is laid, enabling the police to exercise discretion to divert people away from the criminal justice system. In Victoria, police may give a maximum of two successive cautions under the Cannabis Cautioning Program or the Illicit Drug Diversion Program a maximum of two times for use or personal possession of a small amount of cannabis. The person must admit the offence and consent to participate (VLRRCSC 2018, 163-4). Court and police diversion programmes are reported to have been effective in reducing drug use and reoffending (VLRRCSC 2018, 164).

\subsubsection{Community participation}

The pervasiveness and prevalence of community and private entities in formation and implementation of drug policies in Victoria provides a strong contrast with the Chinese drug rehabilitation system. An example is the Yarra Drug and Health Forum, which is a community-based organization that provides a forum for local residents, businesses, and organizations to discuss and advocate for programmes and solutions to local drug-related issues. It receives funding support from local and state government and other organizations. It was heavily involved in advocating for creation of the trial Medically Supervised Injecting Centre in North Richmond and has actively supported making Naloxone available to reduce heroin overdose-related deaths. These groups have close connections with local government, police, health, and education agencies. Police have indicated their support for the trial Medically Supervised Injecting Centre by not patrolling or arresting people in the vicinity.

\subsection{Comparison and Conclusion}


The two case studies presented in this chapter illustrate the dynamic relationship between administrative, judicial, and social power in the formulation and implementation of drug policies in China and the Australian State of Victoria. At one level this is unsurprising and flows from the basic structure of governance. China has traditionally privileged administrative power over judicial power and continues to do so strongly. Courts in China are comparatively weak and this is demonstrated not only in their relatively constrained capacity to resist political interference, but also narrow jurisdictional boundaries ( $\mathrm{Ng}$ and $\mathrm{He}$ 2017.).

Within administrative powers we find in both jurisdictions that the police play a significant role, but clearly in China the police are more central to all aspects of drug policy, from acting as secretariat of the NNCC, to detecting, punishing, rehabilitating, educating, managing, and conducting surveillance of drug users. By contrast, the police’s role in Victoria is more limited. Police diversion programmes in Victoria also provides institutional mechanisms for police to intervene in ways that divert young, first-time, and minor offenders out of the formal criminal justice system and that facilitate their access to programmes directed at addressing underlying problems that have contributed to their offending. Police powers in this field are thus not purely punitive.

The different scopes and lack of balance between administrative and social power also reflects the continuation of the 'big government, small society' mode of governance in China, which tends towards strengthening and expanding the reach of government in areas, such as drug dependency, seen as touching on social stability and national security. In the case of drug policy, strengthening management involves many interlocking mechanisms, from registration, to compulsory orders, to detention. Ultimately though, the expansive intention is not matched by corresponding capacity 
at the local level as the discussion of community-based orders demonstrates. Whilst resources in Victoria are also constrained, in other respects the contrast is stark, in terms of policy orientation and the scope of community engagement. In Victoria, community and non-government groups carry a share of the burden of regulation. In China, this opportunity and burden are limited.

I have not evaluated the comparative efficiency of the two approaches to drug rehabilitation. From the perspective of the lived experience of drug users, neither has been particularly successful in addressing problems of social marginalization and stigmatization. Difficulty in accessing services is a factor in both jurisdictions. In Victoria, criminalization of drug use has been identified as increasing stigmatization and risky forms of drug use (VLRRCSC 2018., 158). In China, registration and the predominance of coercive police power in drug treatment policy is an important factor. It would be interesting to explore which approach was comparatively more successful and why, but that is beyond the scope of this chapter.

Ultimately then, these case studies lead us back to the big picture questions about the purpose and constraints on administrative power, the relationship between state and society and the relationship between law, politics, and administrative power. What has been mapped out at the micro-level also corresponds to the basic principles and priorities of the overarching governance models in each jurisdiction.

\section{References}

Backer, LC. 2009 . 'A Constitutional Court for China within the Chinese Communist Party: Scientific Development and a Reconsideration of the Institutional Role of the CCP’ 43_Suffolk University Law Review_ 593_-624. Baumler., A._.2007_.. The Chinese and Opium under the Republic: Worse than Floods and Wild Beasts. Albany: State University of New York Press. 
Biddulph, S and Xie, C.. 2011. ' Regulating Drug Dependency in China: The 2008 Drug Rehabilitation Law’ 51 British Journal of Criminology _ 978_-996.

Cabestan, J-P... 2019 . Political changes in China since the 19th CCP Congress:

$\mathrm{Xi}$ JInping is not weaker but more contested. East Asia _ 1_ 21.

https://doi.org/10.1007/s12140-019-09305-X

Cane, P. P 2016 . Controlling Administrative Power: An Historical Comparison. Cambridge: Cambridge University Press..

Dutton, M. M 1995 . ‘Dreaming of Better Times: "Repetition with a Difference” and Community Policing in China’ 3 . positions: east asia cultures critique $418-47$.

Frankenberg, G._._1985 . 'Critical Comparisons: Re-thinking Comparative Law' 26 Harvard International Law Journal _411_-55..

Horowitz, D... 2003. ' Forward: Compared to What?' 33 Duke Journal of Comparative International Law _ 1 - 6 .

Jiang, S... 2010_. 'Written and Unwritten Constitutions: A New Approach to the Study of Constitutional Government in China’ 36 _ Modern China _ 12 - 46.

Kahn-Freund, O... 1974 . ' On the Uses and Misuses of Comparative Law' 37. Modern Law Review _ 1 _- 27..

Li., L. . 2015 . “- "Rule of Law” in a Party-State: A Conceptual Interpretive Framework of the Constitutional Reality of China' 2 Asian Journal ofLaw and Society.- $93-113$.

Li, L. 2019 . 'Politics of Anticorruption in China: Paradigm Change of the Party’s Disciplinary Regime 2012 - 2017’_28 Journal of Contemporary China $47-63$. 
Ng, KH and He, X.. 2017_. Embedded Courts: Judicial Decision-Making in

China . Cambridge: Cambridge University Press..

Nicholson, P and Biddulph, S. (eds). 2008.. Examining Practice,

Interrogating Theory: Comparative Legal Studies in Asia.. Leiden/ Boston:

Martinus Nijhoff Publishers.

Ruskola, . T. 2002 . ‘ Legal Orientalism’ 101 Michigan Law Review _..179__ 234 .

Spires, A. 2018 . 'Chinese Youth and Alternative Narratives of Volunteering'

32 China Information 203-23.

State Council Information Office, _2000a...White Paper on Narcotics Control in China.

State Council Information Office, _2000b. White Paper on Narcotics Control, Section IV Treatment and Rehabilitation . <h ttp://www.chinaorgcneWhite11Vhtm>.

Trevaskes, S. . 2018 . 'A Law Unto Itself: Chinese Communist Party Leadership and Yifa Zhiguo in the Xi Era' 44 Modern China _ 347_ 73 .

VLRRCSC, . 2018 . Inquiry into Drug Law Reform in 2018. . Parliament of Victoria, Law Reform, Road and Community Safety Committee, Melbourne...

Xie, L.. 2015 . Practical Exploration of Entrusted Management of Giving up Drugs in the Community and Recovering Health in the Community. Justice of China . . 7 .

Zhang, SX and _Chin, K._. 2018. 'China’s New Long March to Control Illicit Substance Use: From a Punitive Regime towards Harm Reduction’ $11 \ldots$ Journal of Drug Policy Analysis _ 1__ 11 _ _ https://doi.org/10.1515/jdpa-2015-0023> 
Zhang, X. and Li, X. 2015. 'Approaches to the Development of Civic Responsibility against the Background of the "China Dream”, , 10 Theory Horizon $32-8$.

Zhou, Y. and _Wang, D. 2016 . ' Discussion of How to Prevent Drug Harm in the New Situation of the China Dream’ 11_ Legal System and Society... 200 _1 .

Zweigert, K and _Kotz, H...1998. An Introduction to Comparative Law , 3 rd edn.. Oxford: _Clarendon Press.. 


\section{University Library}

\section{- M M I N E R VA A gateway to Melbourne's research publications}

Minerva Access is the Institutional Repository of The University of Melbourne

Author/s:

Biddulph, S

Title:

Administrative Power

Date:

2021

Citation:

Biddulph, S. (2021). Administrative Power. Cane, P (Ed.). Hofmann, H (Ed.). Ip, E (Ed.). Lindseth, P (Ed.). The Oxford Handbook of Comparative Administrative Law, (1), pp.381-395. Oxford University Press.

Persistent Link:

http://hdl.handle.net/11343/252727 